\title{
The Prospect of Duckweed in Pig Nutrition: A Review
}

\author{
Francisca Rumosa Gwaze ${ }^{1} \&$ Marizvikuru Mwale ${ }^{2}$ \\ ${ }^{1}$ Lovedale Public Further Education and Training (PFET) College, Alice, South Africa \\ ${ }^{2}$ Institute for Rural Development, University of Venda, Thohoyandou, South Africa \\ Correspondence: Francisca Rumosa Gwaze, Lovedale Public Further Education and Training (PFET) College, \\ Private Bag X1303, Alice 5700, South Africa. Tel: 27-15-962-8809. E-mail: Tagwaze@gmail.com
}

Received: June 27, 2014 Accepted: November 27, 2014 Online Published: October 15, 2015

doi:10.5539/jas.v7n11p189 URL: http://dx.doi.org/10.5539/jas.v7n11p189

\begin{abstract}
The demand for meat and its products has always exceeded supply. To match the ever-increasing demand, more animal products should be produced. Pig production could be a livestock enterprise of choice since pigs grow rapidly and are ready for marketing in a short time. With the escalating costs of feeds, it is worthwhile to use cheaper alternatives such as duckweed. Duckweed has a potential for full utilisation in the nutrition of the different classes of pigs. Researches have been conducted with different classes of pigs. The aim of this review is to consolidate work that has been conducted on duckweed in the nutrition of all classes of pigs, giving recommendations where necessary. In addition, areas requiring research have also been highlighted.
\end{abstract}

Keywords: biomass, digestibility, Limne, piglets

\section{Introduction}

Demand for animal products, especially in developing countries, is likely to rise significantly as a result of population growth, urbanization, and rising incomes in the face of relatively low levels of consumption at present (Nonhebel \& Kastner, 2011). Consequently, changing climatic conditions are envisaged to lead to veld and crop reduction culminating to in reduction in quantity and quality of meat and meat products (Nardone et al., 2010). It is under such a situation that some invaluable plants are required to feed livestock. Duckweed is one appropriate candidate of such plants. It is an aquatic monocotyledonous plant that is adapted to a wide range of ecological conditions and this makes it to be globally distributed (Landolt, 1986; Leng et al., 1995). Albeit, the plant can be scarce in areas with extremes of precipitation, as well as where temperatures can be as low as $0{ }^{\circ} \mathrm{C}$, it is highly productive. It grows in thick blanket-like mats on still, nutrient-rich, fresh and slightly brackish waters thus the plant serves as nutrient pump; reducing eutrophication and providing oxygen (Azeez \& Sabbar, 2012; Singh et al., 2012). It can also be used to restore derelict ponds (Lottermoser \& Ashley, 2011). Furthermore, because of its favourable nutritional profile and its relatively easy propagation, it is widely used to feed livestock such as pigs (Hassan \& Edwards, 1992).

Pigs have a high reproductive rate, having at least $2 \frac{1}{2}$ farrowings per annum (Chiba, 2010). They are easy to manage and have a fast growth rate although they have a voracious appetite and would need a lot of water for good sanitation purposes (Chiba, 2010). Combining pig productivity and use of duckweed for feeding purposes will allow this animal species to provide the much needed animal protein through meat and meat products to many nations. It should, however, be acknowledged that this livestock species has limited acceptance but it still serves well the purposes of providing nutritious animal protein to those who accept its white meat and meat products (Chiba, 2010). It is, therefore, pertinent to conduct studies that deal with alternative feed sources, such as the duckweed, in a way to enhance the productivity of pigs. The simplicity of the establishment of duckweed, its excellent growth habit, minimal carbon footprint, less land use competition with food crops coupled with other advantages could allow the plant to be deployed in different localities of the world.

\section{The Characteristics of Duckweed}

Duckweed belongs to the botanical family Lemnaceae (which originated from the Greek word "Limne" meaning pond). Duckweed is near-ubiquitous (Leng et al., 1995) but absent in the Polar Regions and deserts, easy to establish and can be produced with minimum costs (Armstrong, 2011). It is a small (1 to $15 \mathrm{~mm}$ ) floating monocotyledonous aquatic plant that consists of five genera which are Lemna, Spirodera, Wolfia, Wolfiella and Landoltia (Table 1: Rusoff et al., 1980; Armstrong, 2011) that comprise about 40 species (Skillicorn et al., 1993; 
Les et al., 2002). The most commonly available species belong to the three genera Lemna, Spirodela and Wolffia. Lemna is the largest genera while Wolffiella species scarcely exist. Duckweed has the distinction of being the smallest angiosperm in the world (Zhao et al., 2012). The plant is identified by the presence of only one root for each small green ovoid frond. Duckweed is capable of both sexual and asexual reproduction, overwintering by producing seeds or turions (Les et al., 2002).

Table 1. Classification of selected species of the family Lemnaceae (Source: Armstrong, 2011)

\begin{tabular}{lllll}
\hline Lemna & Spirodela & Wolffia & Wolffiela & Landoltia \\
\hline L. gibba & S. biperforata & W. microsopia & W. oblonga & L. punctata \\
L. japonica & S. intemediata & W. australiana & W. rotunda & \\
L. minor & S. oligorrhiza & W. neglecta & W.caudate & \\
& S. polyrhiza & W. Columbiana & \\
& S. punctata & & \\
\hline
\end{tabular}

The plant preferentially takes up ammonium, while secreting hydrogen ions, thus creating a reduced-pH environment at the water surface. This low-pH environment is of importance since it reduces ammonia emission to the atmosphere (Chaiprapat et al., 2003) in the context of global warming. Duckweed has a longer growing period than most other plants. In some areas with warm climates, duckweed can grow in all seasons. In addition, the plant has a greater rate of nutrient uptake when compared to other aquatic macrophytes. The growth pattern of duckweed follows a logarithmic fashion (Oron et al., 1986; Wang et al., 2014) doubling in 2 to 7 days (Ge et al., 2012; Okomoda et al., 2012). The yields for the plant can vary from 7.9 (Amali et al., 1999) up to even 55 tonnes (Oron, 1994) per annum per hectare depending on the species, climatic conditions, available surface area, amount of nutrients and management (Ge et al., 2012). Duckweed requires quiescent or slow flowing water. It forms dense floating mats in atrophic ditches and ponds (Driever et al., 2005) containing brackish water. Such characteristics of the duckweed together with its capability to adapt to a wide range of agro-ecological zones, makes it better withstand the effects of climate change compared with other crops and plant species. Besides knowledge on the characteristics aforementioned, it is crucial to have knowledge on the nutritive value of this plant.

\section{The Nutritive Value of Duckweed}

The nutrient content of duckweed is more related to the medium in which the plant grows than on the duckweed species per se (Hassan \& Edwards, 1992). The duckweed plant has no central root system so absorption of nutrients is through the whole plant resulting in direct assimilation of organic molecules through the entire plant. The high growth rate is, therefore, due to the non-structural but metabolically active tissue (Ice \& Couch, 1987).

The water content of duckweed (92 to 95\%) (Yilmaz et al., 1994; Samnang, 1999; Negesse et al., 2009) has an effect on the cost of handling, transportation and drying, especially if the duckweed is to be moved from the site of production. The drying might be accomplished through sun drying (Akter et al., 2011) oven drying (Haustein et al., 1994), par-boiling, pressing or forced air drying (Effiong \& Sanni, 2009). Although it is slow, air drying is the most ideal. Furthermore, value addition to the harvested duckweed plant is paramount. More so, sundried duckweed has been observed in storage for 13 years without any sign of fungal growth and nutrient loss (Mbagwu, 2001) and it has been attributed to the presence of a wax coat on the upper surface of plants which acts as a barrier for fungal growth.

Duckweed has a high protein content of 9 to $20 \%$ in nutrient poor media and 24 to $41 \%$ in nutrient rich media (Ge et al., 2012; Mwale \& Rumosa Gwaze, 2013). The nitrogen levels in the healthy plant are comparable to those in commercial fertilizers; thus, the biomass could also be utilized as a fertilizer supplement (Mbagwu \& Adeniji, 1988). Its protein has a well balanced amino acid profile. As shown in Table 2, duckweed is generally rich in leucine, threonine, valine, phenylalanine and lysine (Rusoff et al., 1980). The methionine and lysine levels, which are essential amino acids, are higher than the levels found in most plant proteins. According to Journey et al. (1991), the concentration levels of methionine and lysine closely resemble that of animal protein. In addition, duckweed contains minerals and vitamins that are essential for the normal functioning of the body (Men et al., 1996). The lipid content is lower (1.8 to $2.5 \%$ ) in duckweed species grown in nutrient-poor water, and generally higher and varying between 3 and 7\% for duckweed grown in nutrient rich water (Kesaano, 2011). 
Effiong and Sanni (2009) established a decreased mold infestation in duckweed (Lemna pausciscostata) and incorporated pelleted fish feeds also highlights its value addition potential with great application in feed storage. Generally, duckweed has low fibre content (5\%) (Kesaano, 2011); however, higher figures have been reported for duckweed plants growing in nutrient rich water. Duckweed can tolerate high nutrient stress and appears to be more resistant to pests and diseases than other aquatic plants (Khang, 2003). Regardless of the attributes that the plant exhibits, it is affected by some environmental conditions.

Table 2. The amino acid composition of various duckweed species (Rusoff et al., 1980)

\begin{tabular}{lllll}
\hline \multirow{2}{*}{ Amino acid (\%) } & \multicolumn{3}{c}{ Plant species } \\
\cline { 2 - 5 } & L. gibba & S. polyrhiza & S. punctata & Wolffia Columbiana \\
\hline Threonine & 3.2 & 3.45 & 3.31 & 2.55 \\
Serine & 2.61 & 2.80 & 2.83 & 2.28 \\
Proline & 2.93 & 3.28 & 2.95 & 2.41 \\
Glycine & 3.79 & 3.95 & 3.93 & 2.04 \\
Alanine & 4.59 & 4.48 & 4.79 & 3.75 \\
Valine & 4.96 & 4.4 & 4.71 & 3.49 \\
Methionine & 0.83 & 0.83 & 1.07 & 0.87 \\
Leucine & 7.15 & 6.85 & 6.88 & 5.83 \\
Lysine & 4.13 & 4.3 & 4.26 & 3.37 \\
\hline
\end{tabular}

\section{Environmental Factors that Influence the Growth of Duckweed}

Despite the resilience duckweed exhibits, the plant is affected by several environmental factors. The plant is unable to survive in unsheltered water bodies and fast moving water (greater than $0.3 \mathrm{~m} / \mathrm{sec}$ ) (Leng et al., 1995). Several studies indicated that wind or movement lead to reduced growth (Edwards et al., 1992; Willet, 2005). At pHs near 9.3, phosphorus will precipitate with calcium and this can result in mineral deficiency leading to slow growth of the plant. Duckweed prefers ammonium $\left(\mathrm{NH}_{4}\right)$ to ammonia $\left(\mathrm{NH}_{3}\right)$, and growth decreases when $\mathrm{NH}_{3}$ levels exceed the levels for $\mathrm{NH}_{4}$ or when $\mathrm{pH}$ exceeds 9.25 (Culley et al., 1981; Al-Nozaily, 2001). The "desirable" exponential growth can quickly lead to aging and decomposition, thereby requiring efficient harvesting. Alaerts et al. (1996) harvested approximately $4.5 \mathrm{mg}(\mathrm{dry}) / \mathrm{m}^{2} \cdot$ day, Willet $(2005)$ harvested $50 \%$ after the biomass had doubled the starting density, while Edwards et al. (1992) harvested every 2-15 days depending on whether it was the dry (warm) or wet (cool) season. Growth rate decreases as biomass accumulates to the point that fronds start overlapping each other (Al-Nozaily, 2001); and this decreases with nutrient depletion (Chaiprapat et al., 2005). Culley et al. (1981) reported that up to $50 \%$ of the nitrogen and phosphorus in the biomass gets released with an interval of more than 20 days between harvests. Continuous harvesting prevents overcrowding, biomass death, and release of nutrients back into the water system (Al-Nozaily, 2001; Nhapi, 2004). However, availability of labour for harvesting the plant might be a limiting factor.

Water temperature has also been proven to have an effect on growth of duckweed. Biomass starts depleting at temperatures below $17{ }^{\circ} \mathrm{C}$, and completely disappeared below $5{ }^{\circ} \mathrm{C}$ (Zimmo et al., 2002). Growth rate also decreased due to competition between species. Wolffia out-competed Lemna species in terms of growth rate but however due to Wolffia's smaller size in nature compared to Lemna species Wolffia yielded less biomass (Edwards, 2005). Aphids and fungi living atop duckweed mats in some instances were associated with reduced growth as well (Zimmo et al., 2004). Besides the nutritional profile of the plant, its economic importance is also fundamental in the plant's analysis.

\section{The Economic Importance of Duckweed}

Duckweed has widely been recommended as an appropriate weed for waste water treatment due to its ability to hyper accumulate various nutrients and toxic metals (Zimmo et al., 2004; Kaur et al., 2010; Azeez \& Sabbar, 2012; Bouali et al., 2012; Khellaf \& Zerdaoui, 2012; Mohedano et al., 2012; Singh et al., 2012). The presence of some tannins and phytic acid in duckweed meal has earned this weed a place in the preservation of feed against spoilage by fungi (Bairagi et al., 2002; Effiong \& Sanni, 2009). Duckweed has also proved that it is a novel source for bio-ethanol production (Xu et al., 2011; Chen et al., 2012; Ge et al., 2012; Muradov et al., 2014). In addition, duckweed (the Wolffia species) has been used as a vegetable in Indochinese Peninsular for many generations (Bhanthumnavin \& Mcgarry, 1971). Moreover, duckweed has been used in the production of insulin, 
pharmaceuticals and other valuable compounds. Of great importance to the farmer and animal nutritionist is the potential of duckweed to provide livestock with feed and that it subsequently has been used in feeding several livestock species (Ahammed et al., 2000; Khandaker et al., 2007; Saroeun et al., 2010). This review, however, focuses on the importance of this plant in pig nutrition.

\section{Use of Duckweed in Pig Nutrition}

Pigs lack the ability to synthesize lysine and methionine, yet these amino acids are essential for metabolism in livestock (McDonald et al., 2010). These amino acids can be obtained from conventional sources. It is the cost, however, that is deterrent to the full utilisation of such sources. It is, therefore, imperative to employ cheaper sources of the required amino acids. In this instance, duckweed contains a wide array of amino acids such as lysine and methionine (Men et al., 1997) which are essential to the nutrition of pigs. Limited research has been conducted on the use of duckweed as feed for pigs (Leng et al., 1995; Men et al., 1996; Rodriguez \& Preston, 1996; 1997; Nguyen Van Lai, 1998; Gutierrez et al., 2001; Dung et al., 2002; Ly et al., 2002). Apart from the favourable amino acid composition, other characteristics such as enrichment in mineral content, Vitamin A and dry matter yield make duckweed plants appropriate ingredients for pig feeds meant for different classes of pigs.

\subsection{Use of Duckweed in Diets Meant for Piglets}

Since piglets grow fast, it is imperative to supply them with a feed that contains nutrients that are able to support such a fast growth rate. Moss (1999) placed piglets (from 0 to 10 days old) on 4 diets; $44 \%$ CP soyabean meal, $20 \%$ replacement of soyabean meal with duckweed, $40 \%$ replacement of soyabean meal with duckweed and $60 \%$ replacement of soyabean meal with duckweed as the supplementary protein. The author observed a significant difference between the 40 and the $60 \%$ duckweed diets on one hand and the control diets on the other hand for average daily gain. No difference existed between the control and the diet that contained duckweed at an inclusion level of $20 \%$. The poorest feed efficiency was observed for the $60 \%$ treatment whilst the highest was observed for the $40 \%$ duckweed treatment. This could be attributed to the fact that, depending on the nutritional profile of the duckweed species that was used, at low inclusion levels, the effects of duckweed is insignificant while at higher $(60 \%)$ levels anti-nutritional factors could be hampering the efficient use of duckweed. However, research on the anti-nutritional factors of duckweed species that are predominantly used as pig feed is paramount to substantiate this assertion. In addition, evaluation of the toxicity levels of these antinutritional factors is crucial. The inclusion level of $40 \%$ duckweed seems ideal in countering the adverse effects associated with the use of duckweed thereby paving way for the efficient utilisation of the plant. More research should, however, be conducted on piglets of different genotypes using different varieties of duckweed before conclusive results are recommended.

Nguyen van Lai (1998) indicated that indigenous piglets found duckweed to be palatable compared to the low intake by Large White piglets. The study proved that Mong Cai (indigenous pigs of Vietnam origin) piglets grew faster than Large White piglets (average daily gain of $200 \mathrm{~g} / \mathrm{d}$ versus $87 \mathrm{~g} / \mathrm{d}$ ). This was attributed to a higher protein intake by Mong Cai piglets $(48.2 \mathrm{~g} / \mathrm{d})$ compared to intake by Large White piglets $(27.9 \mathrm{~g} / \mathrm{d})$. The higher growth rate in the Mong Cai piglets was attributed to the higher protein intake which meant higher proportion of duckweed intake compared to that by Large White pigs. The study showed that there was some interaction between nutrition and genotype. These findings indicated that apart from the factors of palatability and acceptability of feed by the piglets, their duckweed intake and hence growth and development was also influenced by their genetic make-up. It is essential then to conduct studies that determine the effects of genetics on the growth and performance of piglets of various genotypes fed on duckweed. This is crucial in the determination of the ideal inclusion level for each genotype for appreciable growth and development of piglets to porker stage. Studies should also include the effect of the different duckweed species on different piglet genotypes.

Rodriguez and Preston (1996) reported that when fresh duckweed (CP of 30\%) was fed to Mong Cai and Large White piglets as the only supplement to sugar cane juice, the apparent digestibility of the diet DM was 90 and $67 \%$ for the two breeds, respectively. Protein digestibility at this level of duckweed was $73 \%$. Nguyen van Lai and Rodriguez (1998) reported that piglets reflected a higher apparent digestibility of $\mathrm{N}$ of the diet when duckweed was the protein source $(67.3 \%)$ as compared with cassava leaves $(58.9 \%)$ reflecting differences in the concentration of the cell wall material as the small floating water plant has much less need to built-in structural support. Du Thang Hang (1998) further confirmed this when the author indicated that the crude fibre concentration in the dry matter of ensiled cassava leaves was twice as high as in duckweed (15.3 versus $8.3 \%$ ). The authors attributed the higher digestibility of duckweed-based diet to the lower cell wall material of duckweed compared to that of the cassava leaves. The high digestibility of duckweed material was also 
confirmed by Rodriguez and Preston (1996) who reported that N balance increased linearly with increasing duckweed in the diet for pigs. The authors partly credited that to an appropriate amino acid balance of the duckweed protein (Hillman \& Culley, 1978). Not only is duckweed crucial in piglets diets but in mature pigs as well.

\subsection{Use of Duckweed in Diets Meant for Growing and Mature Pigs}

Duckweed has not only been used in piglet nutrition but for mature pigs as well. A high DM digestibility (75\%) for fresh Lemna leaves has been reported by Nguyen van Lai and Preston (2001). Moss (1999) indicated that with weaners, duckweed showed digestibility of nutrients: DM (84 and $82 \%$ for 40 and $60 \%$ duckweed, respectively), CP (82 and 80\% for the 40 and 60\% duckweed), and P (69 and 63\% for 40 and $60 \%$ duckweed). Such high digestibility figures are suitable for feed that is meant for growing pigs. It is important to pay attention to the nutritional profile of the duckweed to be used as feed for the pigs. Haustein et al. (1992) proved that using low protein/high fibre duckweed at an inclusion level of 0,5 and $10 \%$ resulted in a reduction in live-weight of pigs as the level of inclusion of duckweed increased (Table 3). This is because pigs, as monogastric animals, they are not efficient in digesting fibre compared with ruminant animals. Research by Haustein et al. (1992) with a low protein /high fibre duckweed meal ( $23 \% \mathrm{~N}$ and $7.5 \%$ fibre DM) showed that replacing conventional protein sources in diets for growing pigs reduced production and increased feed required per unit growth. This indicates that the Lemna meal used may have been relatively mature since it was low in protein and high in fibre. The authors also speculated that there might have been a high level of oxalate in the duckweed or accumulation of heavy metals or toxins since the duckweed was harvested from a lake. The study indicated that good performance will not be realised if poor quality duckweed is used. It, therefore, implies that it is imperative to consider the source and nutritional profile of the duckweed and to analyse for any potential hazardous substances in the duckweed if anticipated before feeding the pigs.

Van et al. (1996) proved that a diet of ensiled cassava root with $25 \%$ of the protein provided by fresh duckweed can totally replace rice by-products and protein meal in diets for fattening pigs with no reduction in growth rate or conversion rate and with leaner carcasses. This is crucial in mitigating the effects of pigs competing with humans for grain crops such as maize and rice. Other findings have indicated that fresh duckweed used to replace all the soyabean for Mong Cai pigs fed ensiled cassava roots or sugar cane juice (Du et al., 1997; Nguyen van Lai \& Rodriguez, 1998) led to improved performance. The improved performance of pigs fed duckweed was attributed to the high ileal apparent digestibility of organic matter $(81.7 \%)$, crude protein $(73.2 \%)$ and ether extract (59.8\%) of the plant (Du et al., 2009).

Table 3. The live-weight of pigs with Lemna at different inclusion levels (Haustein et al., 1992)

\begin{tabular}{llcc}
\hline \multirow{2}{*}{ Time (d) } & \multicolumn{3}{c}{ Level of Lemna meal in diet (\%) } \\
\cline { 2 - 4 } & 0 & 5 & 10 \\
\hline 1 & 6.9 & 6.8 & 6.8 \\
10 & 9.4 & 9.2 & 9.1 \\
20 & 13.4 & 11.9 & 11.2 \\
30 & 17.4 & 14.6 & 13.2 \\
40 & 23.8 & 19.5 & 17.2 \\
Live-weight gain $(\mathrm{g} / \mathrm{d})$ & 423 & 320 & 260 \\
\hline
\end{tabular}

In a study by Rodriguez and Preston (1996) the authors fed unconventional diets containing duckweed to three pig genotypes (Mong Cai, Large White and Mong Cai X LW), Mong Cai pigs and the crosses utilised the duckweed efficiently. According to these authors as the proportion of the $\mathrm{N}$ intake for duckweed increased, $50 \%$ of the $\mathrm{N}$ in duckweed consumed was stored in the tissues. These authors suggested that the protein of the duckweed plants is readily utilised and has a higher biological value than meals such as those prepared from cassava leaves which are often fed to pigs in the developing countries. The study indicated that duckweed could be well utilised by mature, native pigs. Prior to the establishment of full utilisation of this plant, more research should be conducted using different breeds and different classes such as boars and pregnant sows.

In their study, Rodriguez and Preston (1996) reported that the $\mathrm{N}$ retained as a percentage of $\mathrm{N}$ intake (41\%) and of digested N (57\%) was superior to those reported for cassava meal (1.2\% for $\mathrm{N}$ intake and $-0.31 \%$ of digested 
N). In their comparison of acceptance of duckweed by Large White and Mong Cai pigs, Rodriguez and Preston (1996) reported that Large White pigs could only consume the duckweed plant when sugar cane had been added to the plant because they had not been exposed to duckweed earlier in life whilst Mong Cai pigs had no problems in consuming the duckweed material without sugar cane added to it. A study is required where breeds are exposed to the same feed earlier in life to ascertain if there are pig breed effects on acceptance of duckweed as feed. In their findings, Gutierrez et al. (2001) reported that although pigs fed duckweed consumed more feed and grew faster, the duckweed diet was not digested as efficiently as sorghum/soyabean meal control diet when duckweed was included at $10 \%$ of the diet. The authors attributed this to the high level of fibre $(2.3 \%)$ in the duckweed that was used. It implies that the nutritional profile of duckweed should be established and necessary adjustments be made before using it. Research findings have also indicated the importance of duckweed in the improvement of reproductive parameters in pigs.

\subsection{Duckweed as Feed for Breeding Pigs}

Since breeding pigs have a higher requirement of nutrients than other classes it is mandatory that a nutrient dense diet be supplied. However, such diets are costly. This, therefore, calls for utilisation of feeds such as duckweed. Van et al. (1996) reported a reduction in fat deposition, an improved reproductive performance and decreased economic costs when duckweed was included in diets meant for breeding pigs. This was confirmed by Men et al. (1996) who reported that replacement of 50\% of a conventional protein source (fish meal and soyabean meal) with fresh duckweed in the diets of breeding sows led to larger litter sizes, improved rates of survival and heavier litter weights. A study was conducted by Men et al. (1997) where pregnant sows were placed on four protein supplements; $50 \%$ fish meal, $50 \%$ soyabean meal (at a rate of $150 \mathrm{~g}$ or $200 \mathrm{~g} / \mathrm{d}$ for treatments without duckweed) and, 75 and $100 \mathrm{~g} / \mathrm{d}$ for the treatments with duckweed. Findings from this study indicated no significant difference between diets with and those without duckweed on litter size at birth (8.81 for those with duckweed and 7.44 for those without duckweed), litter size at $21 \mathrm{~d}$ (7.56 versus 5.94) and litter size at 42 day (7.56 for those with duckweed and 5.81 for those without duckweed). However, for the same experiment, the litter weight at birth was higher for those fed duckweed $(8.23 \mathrm{~kg})$ compared to those that had access to feed that did not have duckweed $(6.7 \mathrm{~kg})$. With no difference in litter size between pigs fed duckweed and those fed diets that did not contain duckweed and a higher litter weight for duckweed, it is worthwhile using duckweed as feed for breeding pigs. These authors concluded that replacing half the conventional protein sources (soyabean and fish meal) with fresh duckweed can improve the reproductive performance of sows. They attributed the improved performance to a wide spectrum of amino acids and a high concentration of major and minor minerals, carotene and other pigments such as xanthophylls (Men et al., 1997). With the low cost invested in establishing and harvesting duckweed compared to purchase or formulation of the conventional diets, it therefore is worthwhile using duckweed.

\section{Further Research}

The simplicity of the establishment of duckweed, its excellent growth habit, minimal carbon footprint, less land use competition with food crops coupled with its other advantages should secure duckweed's deployment in different localities of the world (Zhao et al., 2012). It is important to develop a system to use the freshly harvested duckweed on pigs in liquid form in the grower finisher unit. Other forms of duckweed for other livestock classes merit investigation. One form which might be investigated is the use of fresh duckweed as this might go a long way in reducing drying, transportation and storage costs.

Duckweed has been postulated by Eid et al. (1992) and Marten et al. (1996) as a plant with insecticidal properties against the larval stages of mosquitoes. This is another area that requires investigation because if the insecticidal properties are sufficient to control mosquito populations, duckweed will have a positive effect on the health of people residing in mosquito infested areas, especially in those areas where conventional methods of controlling mosquitoes are not feasible. Concerted efforts in research will lead to a renaissance of this excellent novel plant which is highly likely to have a positive impact in sustainable development. Institutions such as the Chengdu institute of Biology (CIB), a Chinese Academy of Science, should be applauded for the effort they are exerting towards research on duckweed i.e. 30 researchers have been tasked to study various aspects relating to duckweed.

\section{Practical Considerations}

Integrated farming could be advocated for wherein for instance pig waste is used to fertilise duckweed fields and gardens. Such integrated systems may include use of pig production excreta to fertilise ponds where duckweed and fish are, duckweed harvested and fed to pigs or any other livestock species. This paves way for possibilities such as using dairy excreta to fertilise duckweed which is then fed to chickens and pigs. Such integrated systems 
are aimed at reducing (or even preventing) loss of nutrients from a farming system (Preston \& Murguetio, 1992). However, cross contamination and hence diseases manifestation should be guarded against.

Most of the village ponds are constructed without proper planning in terms of location, layout and drainage system. Ponds located in the middle of the inhabited area of the village are difficult to drain and have little scope of alterations required for developing duckweed based bio-remediation models. However, ponds at the outskirts of the village are easy to manage as their nutrient rich water can be utilized for irrigating the adjoining agricultural fields. Hence, for full scale commercial utilization of duckweed based bio-remediation models, construction of village ponds is required to be well planned with respect to location, layout and drainage facility. State governments should be encouraged to promote duckweed based bio-remediating models for village ponds through educating people and introducing some rural welfare schemes integrated with village ponds for employment and income generation purposes.

\section{Conclusion}

The duckweed plant is of paramount importance as a feed source for pigs. This serves to meet the demand for meat and meat products to the ever-increasing human populace. The plant has several attributes that include easy establishment, adaptation to a wide range of agro-ecological zones, minimal carbon footprint and high in nutrient composition thereby making it ideal for feeding pigs at various stages of growth. Advocating for the use of duckweed as feed for pigs is critical; however, studies need to be conducted to verify the ideal duckweed species for various genotypes of pigs. Potential of feeding fresh duckweed and testing for the presence of harmful substances before feeding the pigs is crucial.

\section{References}

Ahammad, M. U., Swapon, M. S. R., Yeasmin, T., Rahman, M. S., \& Ali, M. S. (2000). Replacement of sesame oil cake by duckweed (Lemna minor) in broiler diet. Pakistan Journal of Biological Sciences, 6, 1450-1453.

Akter, M., Chowdhury, S. D., Akter, Y., \& Katum, M. A. (2011). Effect of duckweed (Lemna minor) meal in the diet of laying hen and performance and their performance. Bangladesh Research Publication Journal, 5 , 252-261.

Alaerts, G. J., Rehman, M., \& Kelderman, P. (1996). Performance analysis of a full-scale duckweed covered lagoon. Water Research, 30, 843-852. http://dx.doi.org/10.1016/0043-1354(95)00234-0

Al-Nozaily, F. G. (2001). Performance and Process Analysis of Duckweed-Covered Sewage Lagoons for High Strength Sewage - The Case of Sana'a, Yemen (p. 264). Rotterdam, NL: A. A. Balkema.

Amali, E. L., Ofojekwu, P. C., Wade, J. W., \& Ejike, C. (1999). Study on the biomass yield of Duckweed (Lemna minor L.) in hydroponic cultures containing different concentrations of aqueous extract of chicken manure. In 13th Annual Conference of the Fisheries Society of Nigeria (FISON), November 3-8, 1996, New Bussa, Nigeria.

Armstrong, W. P. (2011). The Lemnaceae (Duckweed Family). Retrieved May 29, 2013, from http://waynesword.palomar.edu/1wayindx.htm

Azeez, N. M., \& Sabbar, A. A. (2012). Efficiency of duckweed (Lemna minor L.) in phytotreatment of wastewater pollutants from Basrah Oil Refinery. Journal of Applied Phytotechnology in Environmental Sanitation, 1, 163-172.

Bairagi, A., Sarkar-Ghosh, K. G., \& Sen, S. K. (2002). Duckweed (Lemna polyrrhiza) leaf meal as a source of feedstuff in formulated diets for rohu (Labeorohita Ham) fingerlings afterformulation with a fish intestinal bacterium. Bioresource Technology, 85, 17-23. http://dx.doi.org/10.1016/S0960-8524(02)00067-6

Bhanthumnavin, K., \& Mcgarry, M. (1971).Wolffia arrhiza as a possible source of inexpensive protein. Nature, 232, 495. http://dx.doi.org/10.1038/232495a0

Bouali, M., Zrafi, I., Mouna, F., \& Bakhrouf, A. (2012). Pilot study of constructed wetlands for tertiary wastewater treatment using duckweed and immobilized microalgae. African Journal of Microbiology Research, 6, 6066-6074. http://dx.doi.org/10.5897/ajmr12.455

Chaiprapat, S., Cheng, J. J., Classen, J. J., \& Liehr, S. K. (2005). Role of internal nutrient storage in duckweed growth for swine wastewater treatment. T. ASAE, 48, 2247-2258. http://dx.doi.org/10.13031/2013.20088

Chaiprapat, S., Cheng, J., Classen, J. J., Ducoste, J. J., \& Liehr, S. K. (2003). Modeling nitrogen transport in duckweed pond for secondary treatment of swine wastewater. Journal of Environmental Engineering, 129, 731-739. http://dx.doi.org/10.1061/(ASCE)0733-9372(2003)129:8(731) 
Chen, Q., Jin, Y., Zhang, G., Fang, Y., Xiao, Y., \& Zhao, H. (2012). Improving Production of Bioethanol from Duckweed (Landolti apunctata) by Pectinase Pretreatment. Energies, 5, 3019-3032. http://dx.doi.org/10.3390/en5083019

Chiba, L. I. (2010). Swine Production handbook (13th revision). Retrieved from http://www.ag.auburn.edu/ chibale/swineproduction.html

Culley, J. R., Rejmankova, D. D. E., Kvet, J., \& Frye, J. B. (1981). Production, chemical quality, and use of duckweed (Lemnaceae) in aquaculture, waste management, and animal feeds. Journal of World Mariculture Society, 12, 27-49. http://dx.doi.org/10.1111/j.1749-7345.1981.tb00273.x

Driever, S. M., van Nes, E. H., \& Roijackers, R. M. M. (2005). Growth limitation of Lemna minor due to high plant density. Aquatic Botany, 81, 245-251. http://dx.doi.org/10.1016/j.aquabot.2004.12.002

$\mathrm{Du}, \mathrm{T}$. H. (1998). Ensiled cassava leaves and duckweed as protein sources for fattening pigs on farms in Central Vietnam. Livestock Research for Rural Development, 10, 3. Retrieved May 20, 2013, from http://www.cipav.org.co/lrrd//rrd10/3/hang2.htm

Du, T. H., Nguyen, Q. L., Everts, H., \& Beynen, A. C. (2009). Ileal and total tract digestibility in growing pigs fed cassava root meal and rice bran with inclusion of cassava leaves, sweet potato vine, duckweed and stylosanthes foliage. Livestock Research for Rural Development, 21, 1.

Du, T. H., Nguyen, V. L., Rodríguez, L., \& Ly, J. (1997). Nitrogen digestion and metabolism in Mong Cai pigs fed sugar cane juice and different foliages as sources of protein. Livestock Research for Rural Development, 9, 2. Retrieved June 20, 2014, from http://www.cipav.org.co/lrrd/lrrd9/2/hang92.htm

Dung, N. N. X., Manh, L. H., \& Udén, P. (2002). Tropical fibre sources for pigs-Digestibility, digesta retention and estimation of fibre digestibility in vitro. Animal Feed Science and Technology, 102, 109-124. http://dx.doi.org/10.1016/S0377-8401(02)00253-5

Edwards, P. (2005). Development status of, and prospectus for, wastewater-fed aquaculture in urban environment. In B. Costa-Pierce, A. Desbinnet, P. Edwards \& D. Baker (Ed.), Urban Aquaculture (pp. 45-60). CABI Publishing, UK. http://dx.doi.org/10.1079/9780851998299.0045

Edwards, P., Hassan, M. S., Chao, C. H., \& Pacharaprakiti, C. (1992). Cultivation of duckweeds in septage-loaded earthen ponds. Bioresource Technology, 40, 109-117. http://dx.doi.org/10.1016/0960-8524(92)90195-4

Effiong, B. N., \& Sanni, A. (2009). Effect of Duckweed meal on the rate of mold infestation in stored pelleted fish feed. Advisory Opinion, 1, 26-31.

Eid, M. A. A., Kandil, M. A. E., Moursy, B., \& Sayed, G. E. M. (1992). Bioassays of duck weed vegetation extracts. International Journal of Tropical Insect Science, 13, 741-748. http://dx.doi.org/10.1017/S1742758400007992

Ge, X., Zhang, N., Phillips, G. C., \& Xu, J. (2012). Growing Lemna minor in agricultural wastewater and converting the duckweed biomass to ethanol. Bioresource Technology, 124, 485-488. http://dx.doi.org/10.1016/j.biortech.2012.08.050

Gutierrez, K., Sangines, L., Perez, F., \& Marinez, L. (2001). Use of Studies on the potential of the aquatic plant Lemna gibbafor pig feeding. Cuban Journal of Agricultural Science, 35, 343-348.

Hassan, M. S., \& Edwards, P. (1992). Evaluation of duckweed (L. perpusilla and Spirodela polyrriza) as feed for Nile tilapia (Oreochromis niloticus). Aquaculture, 104, 315-326. http://dx.doi.org/10.1016/0044-8486(92)90213-5

Haustein, A. T., Gillman, R. H., Skillicorn, P. W., Guevara, V., Diaz, F., Vergara, A., \& Gilman, J. B. (1992). Compensatory growth in broiler chicks fed on Lemna gibba. British Journal of Nutrition, 68, 329-335. http://dx.doi.org/10.1079/BJN19920092

Haustein, A. T., Gilman, R. H., Skillicorn, P. W., Hannan, H., Diaz, F., Guevara, V., ... Gilman, J. B. (1994). Performance of broiler chickens fed diets containing duckweed (Lemna gibba). Journal of Agricultural Science, 122, 285-289. http://dx.doi.org/10.1017/S0021859600087475

Hillman, W. S., \& Culley, D. D. (1978). The Uses of Duckweed Amer. Science, 66, 442-51.

Ice, J., \& Couch, R. (1987). Nutrient absorption by duckweed. Journal of Aquatic Plant Management, 25, 30-31. 
Journey, W. K., Skillicorn, P., \& Spira, W. (1991). Duckweed Aquaculture - A New Aquatic Farming System for Developing Countries (p. 76). The World Bank, Washington, DC.

Kaur, L., Gadgil, K., \& Sharma, S. (2010). Effect of pH and lead concentration on phytoremoval of lead from lead contaminated water by Lemna minor. American-Eurasian Journal of Agricultural and Environmental Sciences, 7, 542-550.

Kesaano, M. (2011). Sustainable Management of Duckweed Biomass Grown for Nutrient Control in Municipal Wastewaters. All Graduate Theses and Dissertations, Paper 879. Utah State University.

Khandaker, T., Khan, M. J., Shahjalal, M., \& Rahman, M. M. (2007). Use of duckweed (Lemna perpusilla) as a protein source feed item in the diet of semi-scavenging Jinding layer ducks. Journal of Poultry Science, 44, 314-321. http://dx.doi.org/10.2141/jpsa.44.314

Khang, N. T. K. (2003). Use of duckweed (Lemna minor) as a protein supplement for local (Tau Vang) chicks, and growing and laying hens (MSc Thesis, MEKARN-SLU). Retrieved from http://www.mekarn.org/MSc/theses03/khanlitr.htm

Khellaf, N., \& Zerdaoui, M. (2012). Development of a kinetic model for the removal of zinc using the aquatic macrophyte, Lemna gibba L. Water Science \& Technology, 66, 953-957. http://dx.doi.org/10.2166/wst.2012.262

Landolt, E. (1986). The family of Lemnaceae - A monographic study (Vol. 1, No. 1). Veroffentlichungen des Geobotanischen Institutes der Eidgenossischen Technischen Hochschule, Stiftung Rubel.

Leng, R. A., Stambolie, J. H., \& Bell, R. (1995). Duckweed - A potential high-protein feed resource for domestic animals and fish. Livestock Research for Rural Development, 7, 1. Retrieved June 20, 2014, from http://www.lrrd.cipav.org.co/lrrd7/1/3.htm

Les, D. H., Crawford, D. J. Landolt, E. Gabel, J. D., \& Kimball, R. T. (2002). Phylogeny and systematics of Lemnaceae, the duckweed family. Systematic Botany, 27, 221-240.

Lottermoser, B. G., \& Ashley, P. M. (2011). Trace element uptake by Eleocharis equisetina (spike rush) in an abandoned acid mine tailings pond, northeastern Australia: Implications for land and water reclamation in tropical regions. Environmental Pollution, 159, 3028-3035. http://dx.doi.org/10.1016/j.envpol.2011.04.014

Ly, J., Samkol, P., \& Preston, T. R. (2002). Nutritional evaluation of aquatic plants for pigs: Pepsin/pancreatin digestibility of six plant species. Livestock Research for Rural Development, 14, 1. Retrieved June 24, 2014, from http://www.cipav.org.co/lrrd//rrd14/1/ly141a.htm

Marten, G. G., Suarez, M. F., \& Astaeza, R. (1996). An ecological survey of Anopheles albimanus larval habitats in Colombia. Journal of Vector Ecology, 21, 122-131.

Mbagwu, I. G. (2001). The effect of long-term storage on the nutrient characteristics of Duckweed (Lemna pauciscostata Hegelm). Journal of Arid Agriculture, 11, 147-149. http://dx.doi.org/10.1016/0304-3770(88)90079-4

Mbagwu, I. G., \& Adeniji, H. A. (1988). The nutritional content of duckweed (Lemna pauciscostata Hegelm) in the Kainji Lake area, Nigeria. Aquatic Botany, 29, 357-366.

McDonald, P., Edwards, R. A., Greenhalgh, J. F. D., Morgan, C. A., Sinclair, L. A., \& Wilkinson, R. G. (2010). Animal Nutrition (p. 714). Prentice Hall, Pearson, Toronto.

Men, B. X., Ogle, B., \& Preston, T. R. (1996). Duckweed (Lemna spp) as replacement for roasted soya beans in diets of broken rice for fattening ducks on a small scale farm in the Mekong delta. Livestock Research for Rural Development, 8, 3. Retrieved June 25, 2014, from http://www.cipav.org.co/lrrd8/3/men831

Men, L. T., Bui, H. V., Mai, T. C., \& Preston, T. R. (1997). Effect of dietary protein level and duckweed (Lemna spp) on reproductive performance of pigs fed a diet of ensiled cassava root or cassava root meal. Livestock Research for Rural Development, 9, 1 .

Mohedano, R. A., Rejane, H. R., Costa, R., Flávia, A., Tavares, A., \& Paulo, B. F. (2012). High nutrient removal rate from swine wastes and protein biomass production by full-scale duckweed ponds. Bioresource Technology, 112, 98-104. http://dx.doi.org/10.1016/j.biortech.2012.02.083

Moss, B. S. (1999). Economics and feed value of integrating duckweed production with a swine operation. Submitted to the Graduate Faculty of Texas Tech University in Master of Science, Texas University. 
Muradov, N., Taha, M., Miranda A. F., Kadali, K., Guja, A., Rochfort, S., ... Mouradov, A. (2014). Dual application of duckweed and azolla plants for wastewater treatment and renewable fuels and petrochemicals production. Biotechnology for Biofuels, 7, 30-47. http://dx.doi.org/10.1186/1754-6834-7-30

Mwale, M., \& Rumosa Gwaze, F. (2013). Characteristics of duckweed and its potential as feed source for chickens reared for meat production: A review. Scientific Research and Essays, 8, 689-697.

Nardone, A., Ronchi, B., Lacetera, N., Ranieri, M. S., \& Bernabucci, U. (2010). Effects of climate changes on animal production and sustainability of livestock systems. Livestock Science, 130, 57-69. http://dx.doi.org/10.1016/j.livsci.2010.02.011

Negesse, T. H., Makkar, P. S., \& Becker, K. (2009). Nutritive value of some non-conventional feed resources of Ethiopia determined by chemical analyses and an in vitro gas method. Animal Feed Science and Technology, 154, 204-217. http://dx.doi.org/10.1016/j.anifeedsci.2009.09.010

Nguyen, V. L. (1998). On-farm comparison of Mong Cai and Large White pigs fed ensiled cassava root, rice bran and duckweed. Livestock Research for Rural Development, 10, 3.

Nguyen, V. L., \& Rodríguez, L. (1998). Digestion and N metabolism in Mong Cai and Large White pigs having free access to sugar cane juice or ensiled cassava root supplemented with duckweed or ensiled cassava leaves. Livestock Research for Rural Development, 10, 2. Retrieved May 25, 2014, from http://www.cipav.org.co//rrd/lrrd10/2/lai1021

Nguyen, V., Ly, J., \& Preston, T. R. (2001). In vitro estimates of nitrogen digestibility for pigs and water-soluble nitrogen are correlated in tropical forage feeds. Livestock Research for Rural Development, 13, 1. Retrieved May 25, 2014, from from http:/www.cipav.org.co/lrrd/lrrd13/1/ly131.htm

Nhapi, I. (2004). Potential for the use of duckweed-based pond systems in Zimbabwe. Water SA Association of Crop Science, Uganda, 30, 115-120. http://dx.doi.org/10.4314/wsa.v30i1.5034

Nonhebel, S., \& Kastner, T. (2011). Changing demand for food, livestock feed and biofuels in the past and in the near future. Livestock Science, 139, 3-10. http://dx.doi.org/10.1016/j.livsci.2011.03.021

Okomoda, V. T., Solomon, S. G., \& Ataguba, G. A. (2012). Potential Uses of the Family Lemnacae. Journal of Agriculture and Veterinary Sciences, 4, 1-14.

Oron, G. (1994). Duckweed culture for wastewater renovation and biomass production. Agricultural Water Management, 26, 27-40. http://dx.doi.org/10.1016/0378-3774(94)90022-1

Oron, G., Porath, D., \& Wildschut, L. R. (1986). Wastewater treatment and renovation by different duckweed species. Journal of Environmental Engineering, $112, \quad 247-263$. http://dx.doi.org/10.1061/(ASCE)0733-9372(1986)112:2(247)

Preston, T. R., \& Murguetio, E. (1992). Strategy for sustainable livestock production in the tropics. SAREC and Publishers Consultories para el Desarrollo Rural Integrado en el Tropico Ltda, Cali, Colombia

Rodríguez, L., \& Preston, T. R. (1996). Comparative parameters of digestion and N metabolism in Mong Cai and Mong Cai Large White cross piglets having free access to sugar cane juice and duck weed. Livestock Research for Rural Development, 8, 5. Retrieved May 25, 2014, from http://www.cipav.org.co/lrrd//rrd8/5

Rodríguez, L., \& Preston, T. R. (1997). Local feed resources and indigenous breeds: Fundamental issues in integrated farming systems. Livestock Research for Rural Development, 9, 2. Retrieved May 29, 2014, from http://www.cipav.org.co/lrrd/lrrd9/2/lylian92

Rusoff, L. L., Blakeney, E. W., \& Culley, D. D. (1980). Duckweeds (Lemnaceae): A potential source of protein and amino acids. Journal of Agricultural and Food Chemistry, 28, 848-850. http://dx.doi.org/10.1021/jf60230a040

Samnang, H. (1999). Duckweed versus ground soya beans as supplement for scavenging native chickens in an integrated farming system. Livestock Research for Rural Development, 11, 1. Retrieved May 29, 2014, from http://ftp.sunet.se/wmirror/www.cipav.org.co//rrd//rrd11/1/sam111.htm

Saroeun, K., Ogle, B., Preston, T. R., \& Borin, K. (2010). Feed selection and growth performance of local chickens offered different carbohydrate sources in fresh and dried form supplemented with protein-rich forages. Livestock Research for Rural Development, 22, 225. Retrieved May 29, 2014 from http://www.lrrd.org/lrrd22/12/saro22225.htm 
Singh, D., Tiwari, A., \& Gupta, R. (2012). Phytoremediation of lead from wastewater using aquatic plants. Journal of Agricultural Technology, 8, 1-11.

Skillicorn, P., Spirar, W., \& Journey, W. (1993). Duckweed Aquaculture: A new Aquatic farming system for Developing countries (p. 76). A World Bank Publication. National Agricultural Research Project (NARP), Nigeria.

Van, B. H., Men, L. T., Son, V. V., \& Preston. T. R. (1996). Duckweed (Lemna spp.) as protein supplement in an ensiled cassava root diet for fattening pigs. Livestock Research for Rural Development, 9, 1. Retrieved May 20, 2014, from http://www.cipav.org.co/lrrd//rrd9/1/lemen912.htm

Wang, W., Haberer, G., Gundlach, H., Gläßer, C., Nussbaumer, J., Luo, M. C., ... Messing, J. (2014). The Spirodela polyrhiza genome reveals insights into its neotenous reduction fast growth and aquatic lifestyle. Nature Communications, 5, 3311. http://dx.doi.org/10.1038/ncomms4311

Willett, D. (2005). Duckweed-based wastewater treatment systems: Design aspects and integrated reuse options for Queensland conditions (p. 24). Queensland Department of Primary Industries and Fisheries, DPI \& F Publication's Brisbane. Retrieved from http://www.dcm.nt.gov.au/_data/assets/file/0015/43143/14e.pdf

Xu, J., Zhao, H., Stomp, A., \& Cheng, J. J. (2011). The production of duckweed as a source of biofuels. Biofuels, 3, 589-601. http://dx.doi.org/10.4155/bfs.12.31

Yilmaz, E., Akurt, I., \& Gunal, G. (1994). Use of duckweed, Lemna minor, as a protein feedstuff in practical diets for common carp, Cyprinuscarpio, fry. Turkish Journal of Fish. Aquatic Science, 4, 105-109.

Zhao, H., Appenroth, K., Landesman, L., Salmea, A. A., \& Lam, E. (2012). Duckweed rising at Chengdu: Summary of the 1st International Conference on Duckweed Application and Research. Plant Molecular Biology, 78, 627-632. http://dx.doi.org/10.1007/s11103-012-9889-y

Zimmo, O. R., Al-Sa'ed, R. M., van der Steen, N. P., \& Gijzen, H. J. (2002). Process performance assessment of algae-based and duckweed-based wastewater treatment systems. Water Science Technology, 45, 91-101.

Zimmo, O. R., van der Steen, N. P., \& Gijzen, H. J. (2004). Quantification of the nitrification and denitrification rates in algae and duckweed based wastewater treatment systems. Environmental Technology, 25, 273-282. http://dx.doi.org/10.1080/09593330409355461

\section{Copyrights}

Copyright for this article is retained by the author(s), with first publication rights granted to the journal.

This is an open-access article distributed under the terms and conditions of the Creative Commons Attribution license (http://creativecommons.org/licenses/by/3.0/). 